\title{
Uluslararası kısaltmaların Türkçeye çevirisi
}

\section{Ziya TOK ${ }^{1}$}

APA: Tok, Z. (2019). Uluslararası kısaltmaların Türkçeye çevirisi. RumeliDE Dil ve Edebiyat Araştırmaları Dergisi, (14), 15-23. DOI: 10.29000/rumelide.540990

\section{Öz}

Kısaltma genellikle bir sözcük ya da sözcük grubundaki harflerden yola çıkarak oluşturulan ve hem sözlü dilde hem de yazılı dilde kullanım kolaylığı sağlamayı amaçlayan dilsel bir tür olarak tanımlanır. Genel olarak sözcüklerin ya da kurum ve kuruluş adlarının sözlü ya da yazılı biçimde ifade edilmesi esnasında bu tür bir kullanıma sıkça başvurulur. Özellikle uluslararası düzeyde kurum, kuruluş adı ya da sözcük kısaltması söz konusu olduğunda, diller arasında birtakım kullanım farklılığının olduğu gözlemlenmektedir. Bu tür farklılıklar bir dilden diğerine genel anlamda kısaltmaların oluşturulma yöntemleri ve konuşma dilindeki sesletimi konularında ortaya çıkmaktadır. Diller arası durum söz konusu olduğunda çevirinin kaçınılmaz olduğu aşikardır. Ancak kısaltmaların oluşturulması ve sesletimindeki diller arası farklılıklar çeviride de birtakım güçlükleri beraberinde getirmektedir. Özellikle diller arası çeviride kaynak dildeki bir kısaltmanın hedef dile hangi biçimde ve hangi yöntemle aktarılacağı konusunda zaman zaman güçlükler ortaya çıkabilmektedir. Bu çalışmada uluslararası alanda kullanılan kısaltmaların yazım ve sesletim yönünden Türkçede ve Fransızcada karşılaştırmalı biçimde incelenmesi amaçlanmaktadır. Bu bağlamda kaynak dil olarak Fransızca, erek dil olarak ise Türkçe alınacaktır. Uluslararası ilişkilerle ilgili metinlerden hareketle, Fransızcada kullanılan bir kısaltmanın Türkçede nasıl kullanıldığı ve kısaltmanın her iki dil çifti arasında nasıl çevrildiği örnekler üzerinden incelenecektir. Çalışmada öncelikle kısaltma türleri ve kısaltma oluşturma biçimlerinden kısaca bahsedildikten sonra her iki dildeki kısaltmalar ve kullanımları karşlaştırmalı yöntemle ele alınacaktır.

Anahtar kelimeler: Çeviri, kısaltma, kısaltma türleri, kısaltma oluşturma yöntemleri, çeviri sorunları.

\section{Translation of international abbreviations in Turkish}

\begin{abstract}
The abbreviation is usually defined as a linguistic genre that is formed by the use of letters in a word or phrase and aims to provide ease of use in both the oral language and the written language. In general, this type of use is frequently referred to when the words or names of institutions and organizations are expressed orally or in writing. Especially when there is an institution, organization name or word abbreviation at international level, it is observed that there are some differences between languages. Such differences occur in the methods of creating abbreviations from one language to another in general and in the spoken language. It is obvious that translation is inevitable when there is a language. However, the differences in the formation of abbreviations and interlinguistic differences bring about some difficulties in translation. In particular, inter-lingual translation may occasionally cause difficulties in how and in what way an abbreviation in the source
\end{abstract}

1 Dr. Öğr. Üyesi, Kırıkkale Üniversitesi, Fen-Edebiyat Fakültesi, Batı Dilleri ve Edebiyatları Bölümü, (Kırıkkale / Türkiye), ziya-tok@hotmail.com, ORCID ID: 00oo-0002-7686-9808 [Makale kayıt tarihi: 19.02.2019-kabul tarihi:13.03.2019; DOI: $10.29000 /$ rumelide.540990] 


\begin{abstract}
language will be translated into the target language. This study aims to examine comparatively the abbreviations used in the international field in terms of spelling and pronunciation in Turkish and French. In this context, French will be accepted as the source language and Turkish will be accepted as the target language. Based on the texts on international relations, it will be examined how to use French abbreviation in Turkish and how the abbreviation is translated between these two with examples. After mentioning the types of abbreviation and types of forming abbreviations briefly, abbreviations in both languages and their usage will be studied with a comparative method.
\end{abstract}

Key words: Translation, abbreviation, abbreviation types, types of forming abbreviations, translation problems.

\title{
Giriş
}

Kısaltma Türk Dil Kurumunun Sözlüğüne göre, "Slk kullanılan kelimelerin, şahıs yer ve kuruluş adlarının, yer kazanmak, kolaylık sağlamak gibi pratik amaçlarla yazıda kısaltılmış biçimi:2”olarak tanımlanmaktadır. Tanımdan da anlaşılacağı üzere, bir sözcügün kısaltılarak yazılışı anlamına gelen kısaltma genellikle bir sözcük ya sözcük grubundaki harflerden hareketle oluşturulan ve hem sözlü dilde hem de yazılı dilde kolaylık sağlayan dilsel bir kullanım türüdür. "Başta kurum ve kuruluş adları olmak üzere, birçok kelime veya kelime grubunun kısaltılması anlatımda kolaylık sağlamaktadı»” (Balyemez, 2012:42). Tük Dil Kurumunun yazım kılavuzunda "Kısaltma; bir kelimenin, terimin veya özel adın, içerdiği harflerden biri veya birkaçı ile daha kısa olarak ifade edilmesi ve simgeleştirilmesidir." şeklinde tanımlanıyor. Mustafa Erkan'a göre "simgeleştirme kelimesi hem ticari marka değerini hem de akılda kalma kavramını içine alabilir”. (2016:162). Dolayısıyla burada kısaltmaya başvurmadaki amaçlardan biri simgeleştirerek akılda kahıcılı̆̆ı sağlamaktır.

Türkçede özellikle dini metinlerde eskiden beri kısaltmalar kullanılmaktadır. Osmanlı döneminde de az da olsa bazı kısaltmaların kullanıldığına dair bilgilere rastlamak mümkündür. Özellikle Dünya Posta Birliğinin 1874'te örgütlenmesiyle birlikte bu alanda bazı kısaltmalar Türkçede kullanılmıştır (Erkan, 2016). Buna karşılık, ilk sistemli kullanımın 1900 yılında Şemseddin Sami tarafından kaleme alınan Kamus-i Türki adlı eserde yer aldığı bilinmektedir. Daha sonra 1929 yılında Türk Dil Kurumu tarafından yayımlanan yazım kılavuzunda vesaire sözcügü için v.s. kısaltmasının kullanıldığı görülmektedir. Yine aynı kurum tarafından sonraki yıllarda çıkarılan benzer yayınlarda kısaltmalarla ilgili daha fazla kullanım yer almıştır. (Kalfa, 2005). Bankole (2006) bir sözcük dizisini baş harflerden oluşacak şekilde kısaltma sanatının 5o'li ve 6o'lı yıllarda gelişmeye başladığını belirtir. Dolayısıyla kısaltmalarla ilgili somut çalışmaların çok eski tarihlere dayanmadığı, kısaltma oluşturma ve özellikle bu konuyla ilgili bilimsel çalışmaların son dönemlerde yaygınlaştığı söylenebilir.

Sözcüklerde ya da kurum ve kuruluş adlarının sözlü ya da yazılı biçimde ifade edilmesi esnasında sıkça başvurulan bu kullanım, benzer harflerden kaynaklı olarak bazı durumlarda sorunlar ortaya çıkarabilmektedir. Bu tür sorunlar dil içi kullanımda olduğu kadar diller arası çeviride de görülebilmektedir. Özellikle diller arası çeviride kaynak dildeki bir kısaltmanın hedef dile hangi biçimde ve hangi yöntemle aktarılacağı konusunda zaman zaman güçlükler görülebilmektedir. Ayrıca kısaltmaların her dilde kullanılan alfabenin kurallarına bağlı olarak oluşturulduğu da dikkate alındığında, bu tür güçlüklerin beraberinde çeviri sorunlarını getirdiği söylenebilir. Kısaltmaların oluşturulması ve özellikle bir dildeki kullanımı konusunda uluslararası bir ölçütün bulunmayışı da bu tür sorunların oluşmasında bir etken olarak değerlendirilebilir. Buna ilave olarak, benzer harflerden

2 http://www.tdk.gov.tr/index.php?option=com_bts\&arama=kelime\&guid=TDK.GTS.5c65617469be60.46414074 
hareketle oluşturulan kısaltmalar da yine kaynak dilden hedef dile çeviri sürecinde birtakım sorunlar ortaya çıkarabilir. Her dilde o dilin alfabetik kurallarına uygun olarak kısaltma oluşturulmasıyla ilgili belli başlı yöntemler vardır ve bu yöntemler genellikle birtakım benzerlikler ve farklılıklar içermektedir.

\section{Kısaltma türleri}

Kısaltma oluşturma yöntemlerine bağlı olarak her dilde farklı kısaltma türleri yer almaktadır. Bu da beraberinde farklı kısaltma türlerinin ve kullanımlarının ortaya çıkmasına yol açar. Bununla birlikte, her dildeki kısaltma oluşturma yöntemiyle ilgili değerlendirmeler her ne kadar farklılık içerse de sonuç olarak oluşturulan kısaltma türleri birçok dilde birbirine benzerdir. Türkçede ve Fransızcada genel olarak üç kısaltma türünün olduğu söylenebilir. Bunlar baş harf kısaltması, kısaltma ve kısma ad oluşturmadır.

\section{Baş harf kısaltması (Fr. sigle)}

Baş harf kısaltması, birkaç sözcükten oluşan özellikle kurum, kuruluş, ülke vb. adlarda her sözcüğün ilk harfi alınarak oluşturulan kısaltma türüdür. Örneğin, Avrupa Birliği $\rightarrow A B$, Birleşmiş Milletler $\rightarrow B M$, Amerika Birleşik Devletleri $\rightarrow$ ABD. Baş harf kısaltması birçok dilde olduğu gibi, Fransızcada da aynı biçimde oluşturulur ve kullanılır. Örnek: Union Européenne $\rightarrow$ UE, Fond Monétaire International $\rightarrow$ FMI, Etats-Unis d'Amérique $\rightarrow$ EUA. Bu kısaltma türü daha önce de belirtildiği üzere, çoğunlukla kurum, kuruluş ya da ülke adlarında kullanılır. Bunun dışında, baş harf kısaltması kurum, kuruluş vb. adların dışındaki bazı ifadelerde de görülür. Örneğin DGS $\rightarrow$ Dikey Geçiş Sınavı.

\section{Kisaltma (Fr. abréviation)}

Bazı sözcüklerin ilk harfleriyle birlikte sözcüğü oluşturan temel harflerden birkaçı da alınarak kısaltma oluşturulur. Bu yöntem genellikle sözcüğün ardışık yazılan ilk birkaç harfinden hareketle oluşturulur. Kısaltma "bir sözcükteki birkaç harfin çıkarılması" (Monin, 2014) olarak tanımlanır. Bu kısaltmanın sonunda çoğunlukla nokta bulunur. Örnek: Alm. $\rightarrow$ Almanca, İng. $\rightarrow$ İngilizce. Bu kısaltma türü Fransızcada da aynı şekilde kullanılmaktadır. Örnek: add. $\rightarrow$ addition, fém. $\rightarrow$ féminin.

Berke Vardar’a göre "kısaltma iki biçimde gerçekleşebilir: Güdükleme yoluyla kısaltma (otomobil yerine oto demek gibi) ve eksilti yoluyla kısaltma (pathcan kızartması yerine kızartma demek gibi).” (Vardar, 2002:134). Bu da aslında sözcüğün harflerinden bir kısmının kullanılmasıyla elde edilen bir kısaltma türüdür. Fransızcada da benzer kullanım söz konusudur. Örneğin, kilogramme sözcüğü çoğu zaman kilo biçiminde kullanılır.

\section{Kisma ad (Fr. acronyme)}

Bazı kısaltmalar, sözcüklerin ilk harfleriyle birlikte birkaç harfi alınarak oluşturulur. Burada genellikle akılda kalıcılığa katkı sağlaması amacıyla yeni bir sözcük oluşturulması hedeflenir. Örneğin, Merkezi Nüfus İdaresi Sistemi’nin kısa adı olan MERNís kısaltması ilk bakışta kısaltmadan daha ziyade bir sözcük görünümündedir. Bu kısaltmanın sesletim olarak da kolaylık içerdiği söylenebilir. Aynı şekilde, Türkçe Öğretim Merkezi için TÖMER kısaltması oluşturulmuş ve hatta merkezin adı haline gelmiştir. Bu şekilde oluşturulan kısaltmalarda hangi harflerin kısaltmaya ekleneceği konusunda herhangi bir kesin kısıtlama söz konusu değildir. Örneklerde de görüldüğü gibi, MERNís kısaltmasında ilk sözcüğün ilk üç harfi alınmasına karşın, TÖMER kısaltmasında son sözcüğün ilk üç harfi kısaltmaya eklenmiştir. Benzer kısaltma oluşturma biçimini Fransızcada da görmek mümkündür. Société d'Investissement à 
Capital Variable $\rightarrow$ SICAV Association Française de Normalisation $\rightarrow$ AFNOR. Fransızca örneklerde de görüldüğ̈̈ gibi, kısma ad oluşturulurken sözcüklerin hangi harflerinin alınacă̆ı konusunda kesin bir sinırlama yoktur.

Yukarıda sayılan kısaltma oluşturma yöntemlerine ek olarak, Deliktaşlı'ya göre, "bir diğer kısaltma oluşturma yöntemi kısaltılacak sözcügün birkaç sessiz harfinin alınması yoluyla yapılan kısaltmadır" (2017:144). Bu kısaltma oluşturma yönteminde sözcüğün sessiz harfleri çıkarılır. Benzer kısaltma oluşturma yöntemi Fransızcada da yer almaktadır. Tjs $\rightarrow$ Toujours, qqn $\rightarrow$ quelqu'un.

\section{Kısaltmaların çevirisi ve kullanımı}

Sözcük ya da tümce çevirisinde olduğu gibi kısaltmaların çevirisi konusunda da güçlükler söz konusudur. Bu bağlamda, uluslararası kurum ve kuruluş adlarının kısaltmalarının Türkçeye çevirisinde ve Türkçedeki sesletiminde bazı belirsizlikler olduğu söylenebilir. Örneğin, uluslararası bir kısaltmanın Türkçede kaynak dildeki biçimiyle mi kullanılacağı yoksa Türkçeye çevirisinden hareketle bir kısaltma mı oluşturulacağı çok belirgin değildir. Bununla birlikte, birçok dilde, uluslararası bir kuruluş adının kısaltmasının çevirisi yapılacağı zaman öncelikle o kısaltmayı oluşturan sözcükler o dile çevrilir ve daha sonra ortaya çıkan sözcüklerden bir kısaltma oluşturulur. Örneğin İngilizce adı "International Monetary Fund" olan "Uluslararası Para Fonu"nun kısaltması İngilizcede sözcüklerin baş harflerinden hareketle oluşturulmuştur ve "IMF" biçimindedir. Bu kuruluşun Fransızcada kullanılan kısaltması FMI biçimindedir ve bu kısaltma, kuruluşun adının Fransızcaya çevirisi olan "Fond Monétaire International" ifadesindeki sözcüklerin baş harflerinden oluşturulmuştur. Oysa kısaltmaların sesletimi konusunda Fransızcadaki tutarlı kullanımın Türkçede olduğunu söylemek güçtür. Zira Türkçede bu kuruluşun adının Türkçeye çevirisinden hareketle bir kısaltma oluşturmak yerine İngilizcedeki biçimiyle IMF olarak kullanılması tercih edilmektedir. Dolayısıyla IMF kısaltmasının Türkçede özellikle görselişitsel basında bazen İngilizcedeki sesletimiyle "ayemef" biçiminde söylendiğini duymak mümkündür. Başka bir deyişle kısaltmanın ne çevirisi ne de sesletimi Türkçeye aktarılmaktadır. Oysa Fransızcada bu ve diğer birçok uluslararası kısaltmaların çevirisinde olduğu gibi sesletimi de Fransızcaya aktarılmış durumdadır. Aynı şekilde, UNICEF kısaltması Türkçede yunisef olarak telaffuz edilmektedir. Fransızcada ise alfabeye uygun olarak bu kuruluşun başına Fransızcada belirli tanımlık olan "le" getirilir ve Fransızca sesletime uygun olarak lünisef biçiminde okunur. Bir diğer örnek, İngiliz haber kanalının kısaltması olan BBC harfleri İngilizcede bibisi biçiminde telaffuz edilmektedir. Aynı kısaltma Fransızcada, BBC harflerinin Fransızca okunuşuna uygun olarak bebese biçiminde sesletilir. Ancak bu kısaltma Türkçede İngilizcedeki biçimiyle bibisi biçiminde okunur ve Türkçe alfabe kurallarına uygun olarak bebece biçiminde telaffuz edildiğinde tuhaf karşılanır. Sesletimle ilgili başka bir örnek olarak IBM kısaltması verilebilir. Bu kısaltma Türkçede aybiem biçiminde söylenirken, Fransızlar tarafından ibeem biçiminde yani bu kısaltmadaki harflerin Fransızca alfabesindeki okunuşlarıyla kullanılmaktadır. Burada sesletimle ilgili karşılaştırmalar sadece Türkçe ile Fransızca arasında yapılmaktadır. Çünkü Türkçede harfler her zaman yazıldığı gibi okunur, oysa Fransızca ve diğer birçok dilde harfler sözcük içinde farklı sesletimler içerebilmektedir. Bu da aslında kısaltmaların çevirisi ve okunuşu konusunda diğer dillerden ziyade Türkçede bir sesletim sapması olduğunu göstermektedir. Dolayısıyla bu örneklerden, bir dilde kısaltmaların oluşturulması ve sesletiminin o dilin alfabesinde yer alan kullanım kurallarına uygun olması gerektiği ancak Türkçede buna çok fazla özen gösterilmediği anlaşılabilir.

Bunun dışında, bazı durumlarda, uluslararası bir kurum ya da kuruluş adı Türkçeye çevrilmesine rağmen söz konusu kurum ya da kuruluş adının yabancı dildeki karşılığından hareketle oluşturulan kısaltmasının tercih edildiği görülmektedir. Başka bir deyişle, bazı uluslararası kuruluş adları Türkçeye 
çevrilmesine karşın, kısaltması çevrilmemiştir. Örneğin, Fransızca adı "Banque Arabe pour le Développement Economique en Afrique olan ve Türkçeye Arap Afrika Ekonomik Kalkınma Bankası (İng. Arab Bank for Economic Development in Africa)"biçiminde çevrilen kurum adı için özgün adından hareketle oluşturulan “BADEA” kısaltmasının kullanıldığını görmek mümkündür. Buna benzer örnekleri artırmak mümkündür. $\mathrm{Bu}$ bağlamda, aşağıdaki çizelgede bununla ilgili birkaç örnek verilmiştir.

\begin{tabular}{|c|c|c|c|c|}
\hline Fransızca Adı & $\begin{array}{l}\text { Fransizcada } \\
\text { kullanılan } \\
\text { kisaltması }\end{array}$ & Türkçe Adı & $\begin{array}{l}\text { Türkçede } \\
\text { kullanılan } \\
\text { kısaltılması }\end{array}$ & $\begin{array}{l}\text { İngilizcede } \\
\text { kullanılan } \\
\text { Kisaltılması }\end{array}$ \\
\hline $\begin{array}{l}\text { Association Européenne de } \\
\text { Libre Echange }\end{array}$ & AELE & $\begin{array}{l}\text { Avrupa Serbest } \\
\text { Ticaret Birliği }\end{array}$ & EFTA & EFTA \\
\hline $\begin{array}{l}\text { Association Internationale } \\
\text { de Développement }\end{array}$ & AID & $\begin{array}{l}\text { Uluslararası } \\
\text { Kalkınma Birliği }\end{array}$ & IDA & IDA \\
\hline $\begin{array}{l}\text { Banque Arabe pour le } \\
\text { Développement } \\
\text { Economique de l'Afrique }\end{array}$ & BADEA & $\begin{array}{l}\text { Arap Afrika } \\
\text { Ekonomik } \\
\text { Kalkınma Bankası }\end{array}$ & BADEA & BADEA \\
\hline $\begin{array}{l}\text { Banque des Règlements } \\
\text { Internationaux }\end{array}$ & BRI & $\begin{array}{l}\text { Uluslararası } \\
\text { Ödemeler Bankası }\end{array}$ & BIS & BIS \\
\hline $\begin{array}{l}\text { Conférence des Nations } \\
\text { Unies sur le Commerce et } \\
\text { le Développement }\end{array}$ & CNUCED & $\begin{array}{l}\text { Birleşmiş Milletler } \\
\text { Ticaret ve Kalkınma } \\
\text { Örgütü }\end{array}$ & UNCTAD & UNCTAD \\
\hline $\begin{array}{l}\text { Comite Economique et } \\
\text { Social Européen }\end{array}$ & CESE & $\begin{array}{l}\text { Avrupa Ekonomik } \\
\text { ve Sosyal Komitesi }\end{array}$ & EESC & EESC \\
\hline $\begin{array}{l}\text { Coopération Economique } \\
\text { pour l'Asie Pacifique }\end{array}$ & CEAP & $\begin{array}{l}\text { Asya Pasifik } \\
\text { Ekonomik İşbirliği }\end{array}$ & APEC & APEC \\
\hline $\begin{array}{l}\text { Fonds International de } \\
\text { Développement Agricole }\end{array}$ & FIDA & $\begin{array}{l}\text { Uluslararası } \\
\text { Tarımsal Gelişme } \\
\text { Fonu }\end{array}$ & IFAD & IFAD \\
\hline $\begin{array}{l}\text { Fonds Européen } \\
\text { d'Orientation et de } \\
\text { Garantie Agricole }\end{array}$ & FEOGA & $\begin{array}{l}\text { Avrupa Tarımsal } \\
\text { Yönlendirme ve } \\
\text { Garanti Fonu }\end{array}$ & FEOGA & EAGGF \\
\hline $\begin{array}{l}\text { Fonds Monétaire } \\
\text { International }\end{array}$ & FMI & $\begin{array}{l}\text { Uluslararası Para } \\
\text { Fonu }\end{array}$ & IMF & IMF \\
\hline $\begin{array}{l}\text { Forum International } \\
\text { d'Accréditation }\end{array}$ & FIA & $\begin{array}{l}\text { Uluslararası } \\
\text { Akreditasyon } \\
\text { Forumu }\end{array}$ & IAF & IAF \\
\hline $\begin{array}{l}\text { Guichet Automatique de } \\
\text { Banque }\end{array}$ & GAB & $\begin{array}{l}\text { Otomatik Para } \\
\text { Makinesi }\end{array}$ & ATM & ATM \\
\hline $\begin{array}{l}\text { Organisation de } \\
\text { Coopération et de } \\
\text { Développement } \\
\text { Economique }\end{array}$ & OCDE & $\begin{array}{l}\text { Ekonomik İşbirliği } \\
\text { ve Kalkınma } \\
\text { Teşkilatı }\end{array}$ & OECD & OECD \\
\hline
\end{tabular}




\begin{tabular}{|l|l|l|l|l|}
\hline $\begin{array}{l}\text { Organisation de Normes } \\
\text { Internationales }\end{array}$ & ONI & $\begin{array}{l}\text { Uluslararası } \\
\text { Standartlar Örgütü }\end{array}$ & ISO & ISO \\
\hline $\begin{array}{l}\text { Organisation des Nations } \\
\text { Unies pour le } \\
\text { Développement Industriel }\end{array}$ & ONUDI & $\begin{array}{l}\text { Birleşmiş Milletler } \\
\text { Sanayi Kalkınma } \\
\text { Örgütü }\end{array}$ & UNIDO & UNIDO \\
\hline $\begin{array}{l}\text { Organisation du Traité de } \\
\text { l'Atlantique Nord }\end{array}$ & OTAN & $\begin{array}{l}\text { Kuzey Atlantik } \\
\text { Anlaşması Örgütü }\end{array}$ & NATO & NATO \\
\hline $\begin{array}{l}\text { Organisation } \\
\text { Internationale du Travail }\end{array}$ & OIT & $\begin{array}{l}\text { Uluslararası } \\
\text { Çalışma Örgütü }\end{array}$ & ILO & ILO \\
\hline
\end{tabular}

Çizelge 1. Çevirisi Kullanılmayan Kısaltmalar

Çizelgede de görüldüğü gibi, kurum ve kuruluşların adları Türkçeye çevrilmiş olmasına rağmen, kısaltma konusunda herhangi bir çeviri işlemi söz konusu değildir. Oysa Fransızcada aynı kurumların hem adlarının hem de kısaltmalarının çevrildiği görülmektedir. Türkçede kuruluşun Fransızca ya da İngilizce adından hareketle oluşturulan kısaltmaların yanı sıra, Türkçe adından hareketle oluşturulan ve bu biçimde yerleşen kısaltmalar az da olsa bulunmaktadır. Bu duruma aşağıdaki örnekleri verebiliriz:

\begin{tabular}{|l|l|l|l|l|}
\hline Fransızca Adı & $\begin{array}{l}\text { Fransızcada } \\
\text { kullanılan } \\
\text { kısaltması }\end{array}$ & Türkçe Adı & $\begin{array}{l}\text { Türkçede } \\
\text { kullanılan } \\
\text { kısaltılması }\end{array}$ & $\begin{array}{l}\text { İngilizcede } \\
\text { kullanılan } \\
\text { Kisaltılması }\end{array}$ \\
\hline $\begin{array}{l}\text { Cour Européenne des Droits de } \\
\text { l'Homme }\end{array}$ & CEDH & $\begin{array}{l}\text { Avrupa İnsan } \\
\text { Hakları } \\
\text { Mahkemesi }\end{array}$ & AİHM & ECHR \\
\hline $\begin{array}{l}\text { Organisation Mondiale de } \\
\text { Santé }\end{array}$ & OMS & $\begin{array}{l}\text { Dünya Sağlık } \\
\text { Örgütü DSÖ }\end{array}$ & WHO \\
\hline $\begin{array}{l}\text { Organisation pour la Sécurité } \\
\text { et la Coopération en Europe }\end{array}$ & OSCE & $\begin{array}{l}\text { Avrupa Güvenlik } \\
\text { ve İşbirliği } \\
\text { Teşkilatı }\end{array}$ & AGİT & OSCE \\
\hline L'Union Européenne & L’UE & Avrupa Birliği & AB & EU \\
\hline
\end{tabular}

Çizelge 2. Çevirisi Kullanılan Kısaltmalar

Bu çizelgeden de anlaşılacağı gibi, bazı uluslararası kurum ve kuruluşların hem adı hem de kısaltması Türkçeye aktarılmış, sesletimi de Türkçede yaygın bir kullanım kazanmıştır. Ayrıca, Türk Dil Kurumu sözlüğünün 2011 yılı baskısının son kısmında verilen kısaltmalar listesinde, uluslararası kısaltmaların tümünün Türkçe karşılıklarının verildiği görülmektedir. Bu listeden birkaç örnek aşağıdaki çizelgede verilmiştir.

\begin{tabular}{|l|l|}
\hline Kısaltmanın Türkçesi & Açılımı \\
\hline AAET & Avrupa Atom Enerjisi Topluluğu (European Atomic Energy Community) \\
\hline Ȧ̈HAD & $\begin{array}{l}\text { Avrupa İnsan Hakları Adalet Divanı (Cour Européenne des Droits de } \\
\text { l'Homme }\end{array}$ \\
\hline
\end{tabular}




\begin{tabular}{|l|l|}
\hline BMAEK & $\begin{array}{l}\text { Birleşmiş Milletler Avrupa Ekonomik Komisyonu (United Nations } \\
\text { Economic Commission for Europe }\end{array}$ \\
\hline EİBKT & $\begin{array}{l}\text { Ekonomik İşbirliği ve Kalkınma Teşkilatı (Organization for Economic } \\
\text { Cooperation and Development }\end{array}$ \\
\hline FAB & Federal Araştırma Bürosu (Federal Bureau of Investigation \\
\hline UPF & Uluslararası Para Fonu (International Monetary Fund) \\
\hline
\end{tabular}

Çizelge 3• Çeviri Önerisi Yapılan Kısaltmalar

Çizelge 2 ile çizelge 3 arasındaki en belirgin ayrım kısaltmaların kullanımı ve sesletimidir. Çünkü tüm bu çizelgelerde ve örneklerde de görüldüğü gibi, bu alanda bazı yabancı kuruluş adlarının kısaltması kuruluşun Türkçe adından hareketle oluşturmasına karşın, bazı kuruluş adlarının kısaltmaları ise ya Fransızcada ya da İngilizcede kullanıldığı biçimiyle Türkçeye aktarılmış ve sesletimi de yabancı dildeki biçimiyle kalmıştır. Bu nedenle, TDK sözlüğünde kısaltmalar için verilen çeviri karşllıkları şimdilik sadece öneri olarak kalmıştır. Zira sözlükteki Türkçe kısaltmanın gündelik hayatta kullanımı henüz gerçekleşmiş gibi görünmemektedir. Örneğin, sözlükte IMF kısaltması için verilen UPF karşılığı görsel işitsel basın başta olmak üzere, bu kurumla doğrudan iletişim içinde olan resmi kurumlarca da kullanılmamaktadır, hatta toplumun genelinde imefe ya da ayemef biçiminde yerleşmiştir. Buradan hareketle, Türkçede uluslararası kurum ve kuruluş adlarının kısaltmalarının çevirileriyle ilgili yeterli bir çalışma yapılmadığını, kısmen yapılanların ise öneriden öteye geçemediğini söylemek yerinde olur.

\section{Kisaltmalardaki benzerlik}

Kısaltmalarla ilgili olarak saptamış olduğumuz bir başka güçlük, kısaltmalardaki benzerlikten dolayı bir kısaltmanın birden fazla kuruluş adı için geçerli olabileceği olasılığıdır. Zira bir kuruluşun sadece baş harflerinden hareketle oluşturulan bir kısaltma, başka bir kuruluşun kısaltmasıyla benzerlik gösterebilir. Bu benzerlik, her ne kadar metin içindeki bağlamdan anlaşılabilir olsa da, çeviride güçlük oluşturabilir. Örneğin, “Arap Magrep Birliği” adlı kuruluş için verilen "AMB” kısaltması, aynı zamanda "Avrupa Merkez Bankası" adlı kuruluş için verilen "AMB" kısaltmasıyla benzerdir. Fransızca bankacılıkla ilgili bir metinden Türkçe'ye çeviri yaparken, metin içinde geçen bu iki kuruluş için de aynı kısaltma kullanıldığında, bu durum çeviride belirsizliğe neden olabilir. Yine aynı şekilde TDK kısaltmalar sözlüğünde bir kısaltma için birden fazla karşılık verildiği görülmektedir. Örneğin, ASTB: 1. Amerika Serbest Ticaret Bölgesi. 2. Avrupa Serbest Ticaret Birliği.

Fransızca kuruluş adlarının kısaltmalarının Türkçeye çevirilerinin sadece kuruluşun baş harflerinden hareketle oluşturulmaması, bunun yerine her kuruluşun adında yer alan sözcükler ve heceler yardımıyla belirleyici bir kısaltma yani kısma ad oluşturulması bu sorunun çözümünde yardımcı olabilir. $\mathrm{Bu}$ durumda, bir kısaltmanın hem başka bir kısaltmayla karışması önlenecek hem de kısaltmanın sesletimi kolaylaşacaktır. Örneğin, yukarıda vermiş olduğumuz benzer kısaltmalarla ilgili olarak, "Arap Magrep Birliği” adlı kuruluş için “AMAB”" şeklinde bir kısaltma oluşturulabilir. Aynı şekilde, "Avrupa Merkez Bankası" adlı kuruluş için "AMEB" şeklinde bir kısaltma kullanmak bu tür güçlüklerin aşılmasına yardımcı olabilir. Amerika Serbest Ticaret Bölgesi’nin kısaltmasını Avrupa Serbest Ticaret Bölgesi’nin kısaltmasından ayrıt edebilmek için ise birinciye AMESTİB, diğerine ise ASTİB kısaltması tercih edilebilir. 


\section{Sonuç ve öneriler}

Uluslararası kısaltmaların Türkçeye çevirisi hem çeviri konusunda tutarlılık hem de Türkçenin korunması ve geliştirilmesi bakımından oldukça önemli bir konudur. Zira uluslararası bir kuruluşun kısaltmasının Türkçeye çevrilmemesi ve sesletiminin de kaynak dildeki biçimiyle kullanılması çeviri konusunda bir yetersizliği göstermektedir. Bu noktada, uluslararası kuruluşun kısaltmasının özel ad niteliğinde olduğu ve bu nedenle özgün biçimde kalması gerektiği yönünde değerlendirmeler söz konusu olabilir. Bu tür değerlendirmelere yanıt olarak, İngilizce adı United States of America olan ve kısaltması USA olan Amerika'nın Türkçeye Amerika Birleşik Devletleri biçiminde, kısaltmasının ise ABD biçiminde çevrilmiş olduğunu söylemek yeterli olacaktır. Dolayısıyla, kuruluşun adının çevirisi yapıldığında kısaltmasının da ona göre aktarılması daha sağlıklı bir çeviri olacaktır. Bu bağlamda, TDK’nın bir kısaltma karşılığı önermediği UNICEF kısaltması için de bu kuruluşun adının Türkçeye çevirisiyle birlikte Türkçe bir karşıllk oluşturulabileceğini eklemek gerekir.

Tüm bu değerlendirmelerden hareketle, uluslararası kısaltmalara Türkçe karşılıkların bulunması ve bu karşılıkların kullanımlarının ve Türkçe sesletimlerinin geçerli hale getirilmesi gerektiğini vurgulamak yerinde olur. Bunun için öncelikle Türkçenin doğru kullanımı ve Türkçeye yabancı dilden sözcük geçişi konusunda yasal düzenlemelere ihtiyaç olduğunu belirtmek gerekir. İlk olarak Türkçenin korunması ve geliştirilmesi amacıyla yabancı dilden Türkçeye sözcük geçmesi konusunda bazı sınırlamaların ve kuralların getirilmesi önemlidir. Burada yabancı sözcük ya da kısaltmaların Türkçe karşllıklarının oluşturulması ve kullanılması gerektiğini içeren kanunlar yapılabilir. Zira dilin korunması ve zenginleştirilmesi konusunda birçok ülkenin buna benzer yasal düzenlemeleri mevcuttur. Örneğin Fransa'da 1970'li3 ve 1990'lı yllarda4 bununla ilgili yasal düzenlemeleri görmek mümkündür. Bu düzenlemeler Fransızca dilinin kullanımı ve zenginleştirilmesiyle ilgili yapılan yasal düzenlemelerdir. $\mathrm{Bu}$ düzenlemelerde özetle, ilk olarak bilimsel, teknik ve mesleki alanlarla ilgili bir terimce kurulu oluşturulacağı ve bu kurulun terim üretme konusunda çalışmalar yapacağına dair düzenlemeler yer almaktadır. Ayrıca, herhangi bir yabancı terimin kurul tarafından oluşturulan ve onaylanan bir Fransızca karşılı̆̆ının var olması durumunda, yabancı dildeki karşılığının kullanımı yasaklanmıştır. Buradan hareketle Türkçede de buna benzer biçimde yabancı sözcük kullanımının yasaklanmasıyla ilgili birtakım düzenlemeler yapılabilir.

Türkçede yabancı sözcüklerin kullanımını yasaklayan yasal düzenlemeler tek başına yeterli olmayabilir, bu yüzden yapılacak olan yasal düzenlemeyle birlikte, yabancı sözcüklere Türkçe karşılık üretmetüretme çalışmalarını gerçekleştirmek üzere Türkiye'deki dil ve dilbilim uzmanlarından ve bilimsel, teknik ve mesleki uzmanlardan oluşan bir terimce kurulu oluşturulabilir. Bu kapsamda, uluslararası kısaltmaların Türkçe karşılıkları daha tutarlı bir biçimde oluşturulabilir.

Son aşama türetilen ya da önerilen Türkçe karşlılkların toplumda kullanımının sağlanmasıdır. Zira yukarıda da belirtildiği gibi, TDK sözlüğünde verilen karşıllklar sadece öneri düzeyinde kalmıştır ve toplumda karşılığı olmadığından yetersiz görülmüştür. Bunun için, üretilen ya da çevrilen karşılıkların toplumda kullanımının sağlanması da önemli bir aşamayı oluşturmaktadır. Bu bağlamda, görsel-işitsel basın yayın kuruluşları dilin kullanılması ve kitlelere yayılması konusunda oldukça önemli bir konuma sahiptir. Zira basın-yayın organları daha kısa sürede daha geniş kitlelere ulaşabilen bir yapıya sahiptir. Bu kuruluşlarda, terimce kurulu tarafından türetilen Türkçe kısaltmaların kullanılması zorunlu hale

3 https://www.legifrance.gouv.fr/jo_pdf.do?id=JORFTEXToooooo879206\&pageCourante=00388

4 https://www.legifrance.gouv.fr/affichTexte.do?cidTexte=LEGITEXTooooo5616341 
getirilebilir. Ayrıca basın-yayın kuruluşlarına yönelik olarak Türkçenin geliştirilmesi ve genel olarak Türkçeyi doğru kullanma konusunda teşvik edici bazı çalışmaların yapılması yararlı olabilir.

Sonuç olarak, yabancı kısaltmaların çevirisi, yasal düzenleme başta olmak üzere, kısaltma oluşturma ve bu kısaltmaların kullanımının da içinde olduğu birden fazla aşaması olan bir çalışmayı gerektirir. Bu aşamalardan biri ya da birkaçı gerçekleşmediği zaman yeterli bir sonucun elde edilmesi zor olacaktır. Örneğin, yasal düzenleme yaptıktan sonra, Türkçe kısaltma türetilmesine karşın, o kısaltmanın görselişitsel basında ve kısaltmanın kullanıldığı diğer alanlarda yaygınlaştırılması gerçekleşmezse, bulunan kısaltmalar sadece sözlüklerde ya da akademik çalışmalarda birer öneri olarak kalmaya devam ederler. Bu durumun değişmesi için tüm bu aşamalara ilave olarak, toplumsal bilinci de eklemek gerekir. Zira bütün bu çalışmalar yapılsa bile, toplumda Türkçeyle ilgili olması gereken bilinç tam olarak gerçekleşmediği sürece bir şeylerin eksik kalacağını belirtmekte yarar var. Bunun için, Türkçenin yabancı sözcüklere ve kısaltmalara karşılıkların üretilebileceği zengin ve köklü bir dil olduğunu ve özellikle sesletim konusunda da yazıldığı gibi okunan ve okunması gereken bir dil olduğunu vurgulamak gerekir.

\section{Kaynakça}

Balyemez, S. (2012). TDK İmlâ/Yazım Kılavuzlarının Kısaltmalar Bölümleri Üzerine Bir Değerlendirme, Bartın Üniversitesi, Eğitim Fakültesi Dergisi, Cilt:1, Sayı:1, s.41-57, Bartın.

Bankole, A. (2006). Dealing with Abbreviations in Translation, Translation Journal, Volume: 10, No.4, https://translationjournal.net/journal/38acronyms.htm (E.T. 1.03.2019)

Deliktaşlı, N. (2017). Hukuk Metinlerinde Kullanılan Kısaltmalar ve Çevirileri, Pamukkale Üniversitesi, Sosyal Bilimler Enstitüsü Dergisi, Sayı:29, s.143-152.

Erkan, M. (2016). Türkçede Kısaltmalar ve Bu Alandaki Çalışmalar, Uluslararası Sosyal Araştırmalar Dergisi, Cilt:9, Say1:42, Issn: 1307-9581.

Kalfa, M. (2005). Dilimizde Kısaltmalar Sorunu, Türk Dili Dergisi, Türk Dil Kurumu, sayı: 639.

Lafay, M. (2010). Petit dictionnaire des sigles et acronymes, http://www.ccelrv.com/documents/images/general_photos/151_Fichier.pdf (ET: 14.02.2019)

Monin, S. (2014). La siglaison en langue médicale et problèmes de traduction, ASp, [En ligne], 2/1993, mis en ligne le 26 février 2014, consulté le 30 septembe 2016. URL: http://asp.revues.org/4264.

Türkçe Sözlük, (2011). Türk Dil Kurumu Yayınları, Ankara.

Türk Dil Kurumu (TDK). Kısaltmalar

http://www.tdk.org.tr/index.php?option=com_content\&view=article\&id=198:kisaltmalardizini\&catid=50:yazm-kurallar\&Itemid=132 (ET: 14.02.2019)

Türk Dil Kurumu (TDK). Sözlük

http://www.tdk.gov.tr/index.php?option=com_bts\&arama=kelime\&guid=TDK.GTS.5c65617469be6o .46414074

Türk Dil Kurumu (TDK). Yazım Kllavuzu, kısaltmalar, http://tdk.gov.tr/icerik/yazimkurallari/kisaltmalar/ (ET: 15.02.2019)

Liste d'abréviations, de sigles et de symboles https://www.btb.termiumplus.gc.ca/redacchap?lang $=$ fra\&lettr $=$ chapsect1\&infoo $=1.4($ ET: 15.02 .2019$)$

Vardar, B. (2002). Açılamalı Dilbilim Terimleri Sözlüğü, Multilingual, İstanbul. 